\title{
Serum Amyloid A Protein in the Prediction of Postburn Complications and Fatal Outcome in Patients with Severe Burns
}

\author{
Martin T. Časl, Désirée Coen and Diana Šimić
}

Department of Clinical Chemistry, University Hospital for Traumatology, Zagreb, Croatia

\begin{abstract}
Summary: Fifty adults hospitalized with extensive burns formed the basis of the present study. Serum amyloid A protein, C-reactive protein, $\alpha_{1}$-antichymotrypsin and $\alpha_{1}$-acid glycoprotein were measured in serum samples taken on admission, and 3 and 7 days later. Fatal outcome was observed in 13 out of $14(93 \%)$ patients with serum amyloid A protein over $100 \mathrm{mg} / \mathrm{l}$ on admission and in only 2 of the remaining $36(6 \%)$ patients with serum amyloid A protein below $100 \mathrm{mg} / \mathrm{l}$. The median serum amyloid A protein concentration on admission in 15 patients with fatal outcome was $134 \mathrm{mg} / \mathrm{l}$, and only $30 \mathrm{mg} / \mathrm{l}$ in 35 patients who recovered $(\mathrm{p}<0.00005)$. As a reference value, the level of $100 \mathrm{mg}$ serum amyloid A protein per litre on admission gave an evident predictive value (93\%) and sensitivity (87\%) for fatal outcome. The difference between serum amyloid A protein concentrations in patients with complications (median $642 \mathrm{mg} / \mathrm{l}$ ) and those without complications (median $250 \mathrm{mg} / \mathrm{l}$ ) was statistically very significant $(p=0.0003)$ three days after burn injury. The level of $400 \mathrm{mg} / \mathrm{l}$ as a reference value 3 days after burn injury gave a reasonable predictive value (80\%) and sensitivity $(74 \%)$ for the development of postburn complications, but patients who died did not develop a hypermetabolic reaction and their serum amyloid A protein concentration remained below $400 \mathrm{mg} / \mathrm{l}$, despite high serum amyloid A protein concentrations observed on admission (above $100 \mathrm{mg} / \mathrm{l}$ ). No statistical significance was observed for the other 3 acute phase proteins investigated in this study.
\end{abstract}

\section{Introduction}

Thermal injury is caused by overheating of body tissues above the critical temperature, leading to tissue damage. The pathophysiology of the burn syndrome is characterized by the burn wound, its infection and the host's impaired defence to it, hypermetabolism and increased energy demand. Vital postburn complications are: pulmonary insufficiency, renal insufficiency and complications involving the gastrointestinal tract (1).

Tissue damage, including burns, leads to considerable changes in plasma proteins, a reaction commonly referred to as "the acute phase response". The concentration of many plasma proteins, derived largely from the liver, changes during inflammation. These are known as acute phase proteins. Severely burned patients display a strong acute phase response in the first hours to days after burn injury. They often have a high fever within 24 hours and produce acute phase proteins (2). A reliable marker of acute phase response must fulfill the following criteria: a rapid and substantial increase in concentration following an inflammatory stimulus and a short half-life in circulation (3). Although some 34 known plasma proteins increase in concentration during inflammation, only two of them are suitable markers of acute phase response: serum amyloid A protein and Creactive protein $(4-6)$. Both are quick to respond and both increase substantially in severe inflammation, but serum amyloid A protein is the more sensitive quantity (6-9). It shows a more than 1000 -fold increase in plasma concentration a few hours (4-6) after inflammatory stimulus (3), and has a very short half life of between 75 and 90 minutes $(10,11)$. Serum amyloid A protein is an apolipoprotein of very low density (VLDL) and high density lipoproteins (HDL) (12) and may have an important role in the removal of excess cholesterol from phagocytosing macrophages. It is probably a recognition marker for liver uptake of HDL-bound cholesterol, hence its clearance from the circulation (3). It has been shown that serum amyloid A protein-enriched HDL are catabolized more rapidly than normal HDL. Possibly HDL and perhaps also VLDL may function to remove non-polar toxins or cellular constituents from sites of injury and transport them to the liver for detoxification (13).

The aim of the present study was to evaluate the behaviour of serum amyloid A protein together with the other three most important acute phase proteins: C-reactive protein, $\alpha_{1}$-antichymotrypsin and $\alpha_{1}$-acid glycoprotein in the early phases of severe burns, in order to determine the statistical significance of these biochemical indicators for the early prediction of postburn complications and fatal outcome. 


\section{Patients and Methods}

The study group comprised 50 adults (aged between 21 and 82 years. mean age 45 ) with total body surface area burns greater than $20 \%$ (range from 20 to $95 \%$, mean $42 \%$ ). All patients received a uniform regime of treatment consisting of standard fluid resuscitation, nutritional support, plasma expanders, fresh frozen plasma and prophylactic antibiotic therapy. A topical antimicrobial agent, silver sulfadiazine, ivas applied to delay the onset of and decrease the level of bacterial colonization. The first blood samples were taken immediately upon admission and subsequently on days 3 and 7 after the burn injury. Sera from patients who developed complications were taken every day during that period. Sera were stored at $-20^{\circ} \mathrm{C}$ and assayed in batches at the end of the study. Serum amyloid $\mathrm{A}$ protein concentrations were determined by the micro ELISA test (14) with a sensitivity of $0.1 \mathrm{mg} / \mathrm{l}$ and precision expressed as coefficients of variation between 1.6 and $4.2 \%$. Immunoaffinity-purified sequence-specific antibody against serum amyloid A protein (15) was obtained from Tinolab (Zagreb, Coratia). C-reactive protein, $\alpha_{1}$-antichymotrypsin and $\alpha_{1}$-acid glycoprotein were determined by the method of Mancini et al. (16) with a sensitivity of $5 \mathrm{mg} / \mathrm{l}$ and coefficients of variation below $5 \%$. Specific antibodies against $\mathrm{C}$-reactive protein were obtained from Roche Diagnostica (Basel, Switzerland) while specific antibodies against $\alpha_{1}$-antichymotrypsin and $\alpha_{1}$-acid glycoprotein, human serum $C$-reactive protein calibrator and human serum protein calibrator (for $\alpha_{1}$-antichymotrypsin and $\alpha_{1}$-acid glycoprotein standardization) were purchased from Dako (Glostrup, Denmark). The statistical significance was calculated using the Mann-Whitney U test.

\section{Results}

Figure 1 shows the changes of the median concentrations of all four acute phase proteins during the course of 7 days. Altogether 27 patients (54\%) developed postburn complications and 15 patients $(30 \%)$ had fatal outcome. The average age of the survivors was 40 years, and that of the non-survivors was 55 years. The survivors had less severe burns, with a mean total body surface area burn of $37 \%$, while the non-survivors had a mean total body surface area burn of $46 \%$.

According to these findings, patients were divided into two groups: survivors (35 patients) and non-survivors (15 patients). The same patients were again divided into

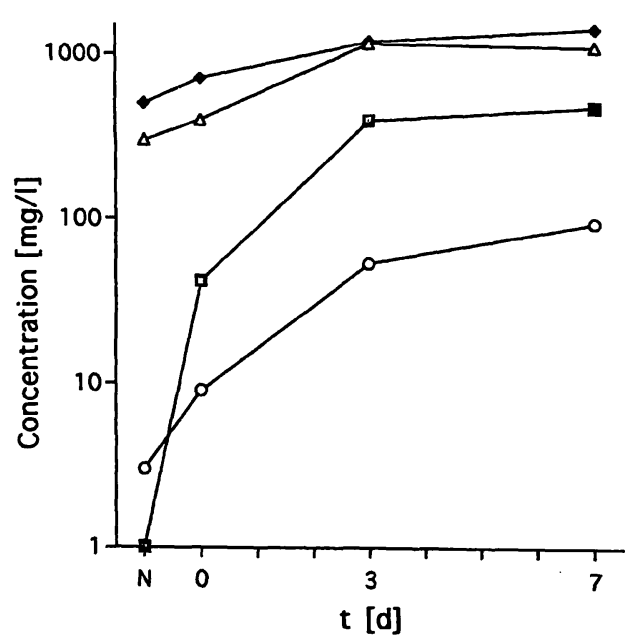

Fig. 1 Seven days follow-up of: serum amyloid A protein (घ), Creactive protein $(0), \alpha_{1}$-antichymotrypsin $(\Delta)$ and $\alpha_{1}$-acid glycoprotein $(\diamond)$ concentrations in 50 patients with severe burns. Each data point is the group median value. $\mathrm{N}$ denotes normal value. two further groups: those who developed postburn complications (27 patients) and those who did not (23 patients). Results are presented in figure 2.

Fatal outcome was observed in 13 out of 14 (93\%) patients with serum amyloid A protein concentrations above $100 \mathrm{mg} / \mathrm{l}$ on admission and in only 2 of the remaining $36(6 \%)$ patients with serum amyloid A protein concentrations below $100 \mathrm{mg} / \mathrm{l}$. The median serum amyloid A protein concentration on admission in 15 patients with fatal outcome was $134 \mathrm{mg} / \mathrm{l}$ and only $30 \mathrm{mg} / \mathrm{l}$ in 35 patients that recovered $(p<0.00005, U=70)$; the normal mean (reference) value for 30 healthy adults was $0.8 \mathrm{mg} / 1$, range $<0.1-1.2 \mathrm{mg} / 1$. The difference between serum amyloid A protein concentrations in patients who later developed complications (with median serum amyloid A protein value of $642 \mathrm{mg} / \mathrm{l}$ on day 3 and 1050 $\mathrm{mg} / \mathrm{l}$ on day 7) and those who did not (with median serum amyloid A protein value of $250 \mathrm{mg} / \mathrm{l}$ on day 3 and $175 \mathrm{mg} / \mathrm{l}$ on day 7) was statistically very significant $(\mathrm{p}=0.0003, \mathrm{U}=125$ and $\mathrm{p}<0.00005, \mathrm{U}=85$, three and seven days after burn injury, respectively).

Fatal outcome was observed in 9 out of 23 . (39\%) patients with C-reactive protein values above $10 \mathrm{mg} / \mathrm{l}$ on admission and in 6 out of the remaining $27(22 \%)$ patients with C-reactive protein values below $10 \mathrm{mg} / \mathrm{l}$. The median C-reactive protein concentration on admission in 15 patients with fatal outcome was $17 \mathrm{mg} / \mathrm{l}$ and $9 \mathrm{mg} / \mathrm{l}$ in 35 patients that recovered $(p=0.221, U=205)$; mean value of 30 healthy adults was below $5 \mathrm{mg} / \mathrm{l}$. There was no statistically significant difference on admission or three days later between $\mathrm{C}$-reactive protein values in patients who developed complications and those who did not (median C-reactive protein values of 60 and $53 \mathrm{mg} / \mathrm{l}$ on day 3 , respectively), but it was very high 7 days after burn injury $(p<0.00005, U=82$; with median C-reactive protein values of 134 and 40 $\mathrm{mg} / \mathrm{l}$, respectively).

Fatal outcome was observed in 9 out of 21 (43\%) patients with $\alpha_{1}$-antichymotrypsin values above $0.40 \mathrm{~g} / \mathrm{l}$ on admission and in 6 out of remaining $29(21 \%)$ patients with $\alpha_{1}$-antichymotrypsin values below $0.40 \mathrm{~g} / \mathrm{l}$. The median $\alpha_{1}$-antichymotrypsin value of admission in 15 patients with fatal outcome was $0.47 \mathrm{~g} / \mathrm{l}$ and $0.39 \mathrm{~g} / \mathrm{l}$ in 35 patients that recovered $(p=0.015, U=180)$. There was no statistically significant difference on admission between $\alpha_{1}$-antichymotrypsin values in patients who developed complications and those who did not, but significant differences were observed 3 and 7 days after burn injury $(p=0.0452, U=203$ and $p=0.017, U=181$, respectively).

Fatal outcome was observed in 10 out of $25(40 \%)$ patients with $\alpha_{1}$-acid glycoprotein concentrations above $0.70 \mathrm{~g} / 1$ on admission and in 5 out of the remaining 25 (20\%) patients with $\alpha_{1}$-acid glycoprotein values below 
$0.70 \mathrm{~g} / \mathrm{l}$. The median $\alpha_{1}$-acid glycoprotein value on admission in 15 patients with fatal outcome was $0.76 \mathrm{~g} / \mathrm{l}$ and $0.70 \mathrm{~g} / 1$ in 35 patients that recovered, with no statistically significant difference. There was also no statistically significant difference during the investigated period between patients who developed complications and those who did not.

There was no correlation among the concentrations of acute phase proteins on admission or later.

\section{Discussion}

Our results show that severe burns induce a dramatic acute phase response within the first hours of injury. Peak levels of serum amyloid A protein and C-reactive protein were increased up to 3000 - and 100-fold above normal concentrations, respectively. $\alpha_{1}$-Antichymotryp$\sin$ and $\alpha_{1}$-acid glycoprotein peak levels were increased up to sixfold above their normal values. These findings are very similar to our previous observations with acute phase proteins in patients with acute myocardial infarction (8). On admission to hospital, the ratio between serum amyloid $A$ protein and $C$-reactive protein levels was usually between $5: 1$ and $11: 1$, which is similar to those observed during kidney allograft rejection $(10: 1)$ (17-19), influenza (11:1) or pneumonia $(7: 1)$ (9). The ratio between serum amyloid $\mathrm{A}$ protein and $\mathrm{C}$-reactive protein was more increased 7 days after burn injury, and in same cases with postburn complications it was higher than $30: 1$, which we believe is the highest ratio ever
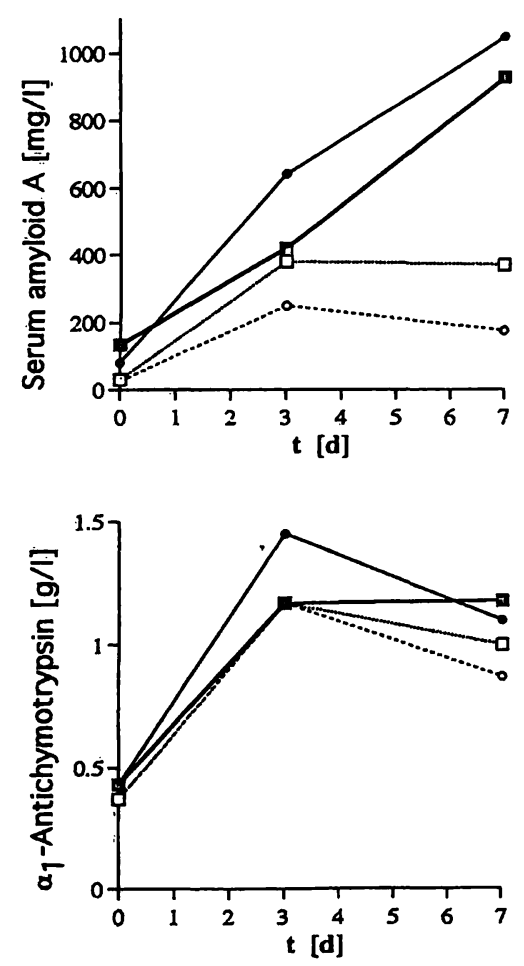

Fig. 2 Comparison among acute phase protein concentrations in four groups of patients with severe burns: patients with fatal outcome (回) and survivors (ㅁ); patients who developed postburn reported, although we measured higher individual serum amyloid A protein concentrations in the sera of patients with acute myocardial infarction (9). In patients who developed postburn infections or sepsis, we found higher serum amyloid A protein values and a higher serum amyloid A protein/C-reactive protein ratio than we had observed earlier in patients with urinary tract infections $(5: 1)(6)$ or in neutropenic patients with acute leukaemia during their infectious febrile episodes $(1: 1$ to $5:$ 1) (7).

Results from this study suggest that postburn complications and fatal outcome are closey correlated with the serum amyloid A protein values determined on admission and three days later. As a reference value, the level of $100 \mathrm{mg} / \mathrm{l}$ on admission gave an evident predictive value $(93 \%)$ and sensitivity $(87 \%)$ for fatal outcome. The level of $400 \mathrm{mg} / \mathrm{l}$, as a reference value 3 days after burn injury, gave a reasonable predictive value $(80 \%)$ and sensitivity (74\%) for the development of postburn complications. Patients who died did not develop a hypermetabolic reaction and their serum amyloid $A$ protein levels remained below $400 \mathrm{mg} / \mathrm{l}$, despite high levels (above $100 \mathrm{mg} / \mathrm{l}$ ) on admission.

It was not possible to identify any $\mathrm{C}$-reactive protein level on admission or later which would give a reasonable predictive value and sensitivity for mortality rate. The best results on admission were obtained with a level of $10 \mathrm{mg} / \mathrm{l}$ but with a poor predictive value $(39 \%)$ and sensitivity $(60 \%)$. Seven days later a level of $100 \mathrm{mg} / \mathrm{l}$ as reference value gave a good sensitivity for mortality
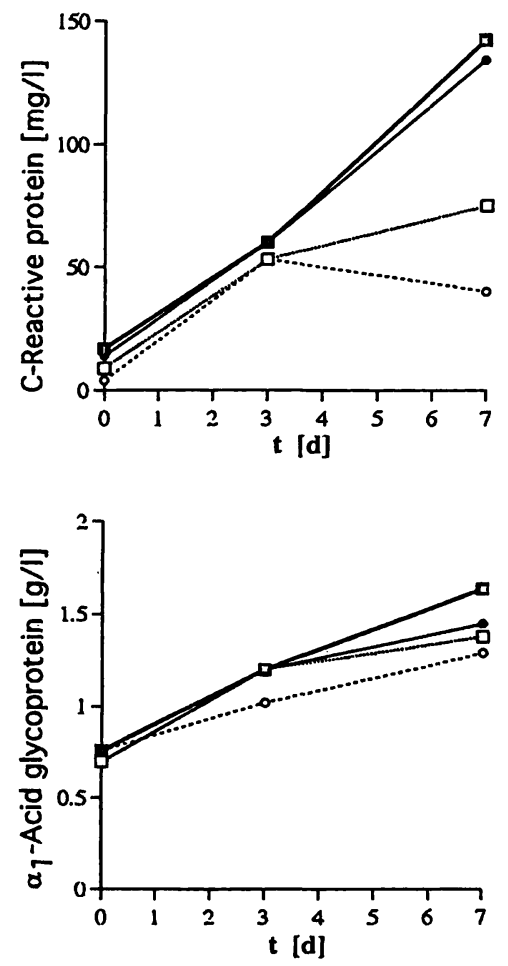

complications $(\bullet)$ and patients who recovered without complications (0). Each data point is the group median value. 


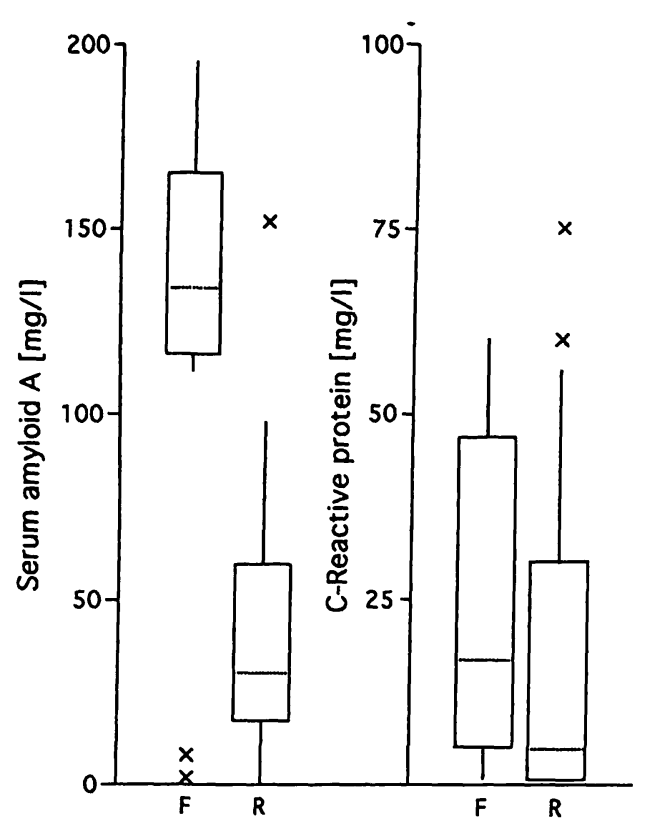

Fig. 3 Multiple box-and-whisker plot for serum amyloid A protein and $C$-reactive protein values on admission. Group $F=$ patients with fatal outcome; group $\mathrm{R}=$ patients who recovered (survivors).

rate $(11 / 15 ; 73 \%)$ with no predictive value $(11 / 24 ; 46 \%)$ but with a good predictive value $(20 / 24 ; 83 \%)$ and sensitivity $(20 / 27 ; 74 \%)$ for developing postburn complications.

Similarly, it was not possible to identify an $\alpha_{1}$-antichymotrypsin level on admission or later which would give a reasonable predictive value and sensitivity for mortality rate. The best results on admission were obtained with a level of $0.40 \mathrm{~g} / \mathrm{l}$ but with a poor predictive value $(43 \%)$ and sensitivity (60\%). As a reference value, 1.00 g/l gave a good sensitivity for mortality rate $(12 / 15$; $80 \%)$ with no predictive value $(12 / 27 ; 44 \%)$ but with a poor predictive value and sensitivity $(18 / 27 ; 67 \%)$ for developing postburn complications.

There was no $\alpha_{1}$-acid glycoprotein level on admission or later which would give a reasonable predictive value and sensitivity for mortality rate. The best results were obtained with a level of $0.70 \mathrm{~g} / 1$ on admis-

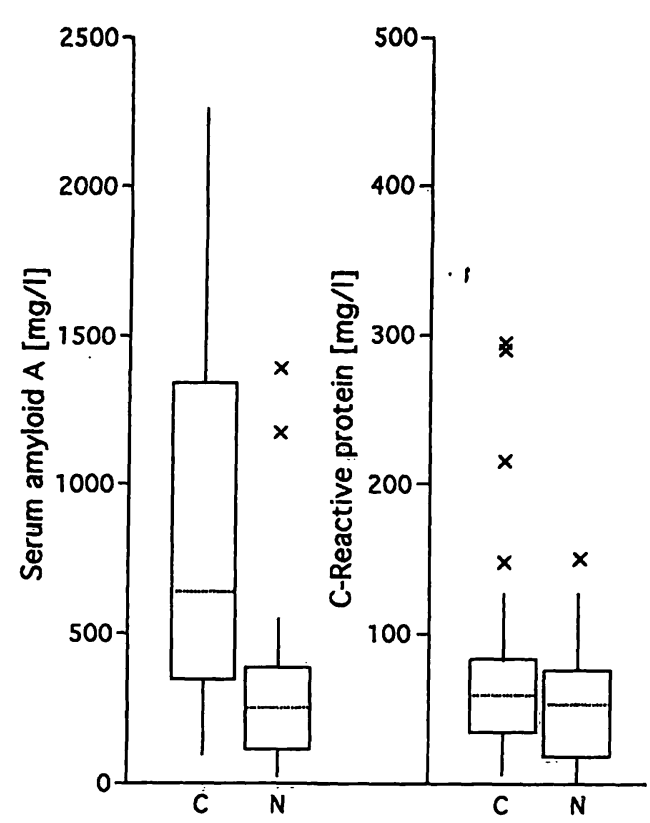

Fig. 4 Multiple box-and-whisker plot for serum amyloid A protein and $\mathrm{C}$-reactive protein values three days after admission. Group $\mathrm{C}=$ patients who developed postburn complications; group $\mathrm{N}=$ patients who did not develop postburn complications.

sion but with a poor sensitivity (67\%) and no predictive value $(40 \%)$

According to the results presented in this study, we conclude that serum amyloid A protein is the best of all the four acute phase proteins investigated as a marker for early prediction of postburn complications and fatal outcome, even in the very early phase. Negligible overlap of serum amyloid A protein data in multiple box-andwhisker plots presented in figures 3 and 4 suggests that serum amyloid A protein is a very useful clinical laboratory quantity for differentiating patients with severe burns at the very beginning of the injury.

\section{Acknowledgements}

This research was supported by a grant from the Ministry of Science, Republic of Croatia (Project No. 3-01-272). Part of this work was presented at the XV International Congress of Clinical Chemistry (Melbourne, 1993) and appeared in abstract form in The Clinical Biochemists-Reviews 1993; 14:211.

\section{References}

1. Arturson MG. The pathophysiology of severe thermal injury. J Burn Care Rehab 1985; 6:129-6.

2. Nijsten MWN, Hack Ce, Helle $M$, ten Duis HJ, Klasen HJ, Aarden LA. Interleukin- 6 and its relation to the humoral immune response and clinical parameters in burned patients. Surgery 1991; 109:761-7.

3. Chambers RE, Whicher JT, Dieppe PA. Acute phase proteins in inflammatory diseases. Clin Diag Lab 1989; 1:29-37.

4. Schultz DR, Arnold PI. Properties of four acute phase proteins: C-reactive protein, serum amyloid A protein, $\alpha_{1}$-acid glycoprotein and fibrinogen. Semin Arthritis Rheum 1990; 20:129-7.

5. Thompson D, Milford-Ward A, Whicher JT. The value of acute phase protein measurements in clinical practice. Ann Clin Biochem 1992; 29:123-31.

6. Časl MT, Sabljar-Matovinović M, Kovačević S, Počanić D, Preden-Kereković V, Jagarinec N. Clinical relevance of serum

amyloid A protein monitoring in urinary tract infections. Ann Clin Biochem 1993; 30:272-7.

7. Časl MT, Rogina B, Glojnarić-Spasić I, Minigo H, PlanincPeraica Y, Jakšić B. The differential diagnostic capacity of serum amyloid $A$ protein between infectious and non-infectious febrile episodes of neutropenic patients with acute leukemia. Leukemia Res 1994; 18:665-70.

8. Časl MT, Šurina B, Glojnarić-Spasić I, Pape E, Jagarinec N, Kranjčević $S$. Serum amyloid A protein in patients with acute myocardial infarction. Ann Clin Biochem 1995; 32:196-200.

9. Nakayama T, Sonoda S, Urano T, Yamada T, Okada M. Monitoring both serum amyloid protein $\mathrm{A}$ and $\mathrm{C}$-reactive protein as inflammatory markers in infectious diseases. Clin Chem 1993; 39:293-7.

10. Maury CPJ. Comparative study of serum amyloid A protein and C-reactive protein in disease. Clin Sci 1985; 68:233-8. 
11. Tape C, Kisilevsky R. Apolipoprotein A-I and serum amyloid A protein half-lives during acute inflammation and amyloidogenesis. Biochim Biophys Acta 1990; 1043:295-300.

12. Feussner $G$, Ziegler $R$. Detection of serum amyloid A protein in very low density and high density lipoproteins of patients after acute myocardial infarction. Electrophoresis 1989; 10:776-80.

13. Parks JS, Rudel LL. Metabolism of the serum amyloid A proteins (SAA) in high-density lipoproteins and chylomicrons of non human primates (vervet monkey). Am J Pathol 1983; 112:243-9.

14. Časl MT, Grubb A. A rapid enzyme-linked immunosorbent assay (ELISA) for serum amyloid A (SAA) using sequencespecific antibodies. Ann Clin Biochem 1993; 30:278-86.

15. Grubb A, Löfberg $H$, Thysell $H$, Ljungren $L$, Olsson $T$, Skinner $M$, et al. Production of an amino acid sequencespecific antiserum against human amyloid $A(A A)$ and serum amyloid $A$ (SAA) protein. Scand $J$ Clin Lab Invest 1987; 47:619-26.
16. Mancini G, Carbonara AO, Heremans JF. Immunochemical quantiation of antigens by single radial immunodiffusion. Immunochemistry $1965 ; 2: 235-54$.

17. Maury CPJ, Teppo AM. Comparative study of serum amyloidrelated protein SAA, C-reactive protein, and $\beta_{2}$-microglobulin as markers of renal allograft rejection. Clin Nephrol 1984; 22:284-92.

18. Časl MT, Bulatović G, Orlić P, Sabljar-Matovinović M. Serum amyloid A protein monitoring for early prediction of kidney allograft rejection Nephron 1995; 70:112-3.

19. ČasI MT, Bulatović G, Orlić P, Sabljar-Matovinović M. The diagnostic capacity of serum amyloid A protein for early recognition of kidney allograft rejection. Nephrol Dial Transplant 1995; 10: 1901-4.

Received June 15/October 6, 1995

Corresponding author: Dr. Martin-Tino Časl, Nova Ves 36, HR-10000 Zagreb, Croatia 
